\title{
Management of the Independent Learning Curriculum during the Covid-19 Pandemic
}

\author{
Istaryatiningtias ${ }^{1}{ }^{*}$, Silviana, $\mathrm{L.}^{2}{ }^{2}$, Hidayat , $\mathrm{E}^{3}{ }^{3}$ \\ 1,2,3 Postgraduate Study Program, Universitas Muhammadiyah Prof. DR. HAMKA, Jakarta, Indonesia
}

\section{A R T I CLE IN F O}

Article history:

Received March 10, 2021

Revised March 11, 2021

Accepted April 24, 2021

Available online May 25, 2021

Kata Kunci :

Education, Curriculum, PJJ

Keywords:

Education, Curriculum, Distance Learning

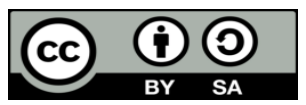

This is an open access article under the CC BY-SA license.

Copyright $\odot 2021$ by Author. Published by Universitas Pendidikan Ganesha

\begin{abstract}
A B S T R A K
Kurikulum merupakan sesuatu yang tidak dapat dihindari dalam berinteraksi dengan lingkungan pendidikan. Covid-19 yang telah menjadi pandemi di lebih dari 200 negara di dunia, menuntut perubahan di berbagai bidang, termasuk pendidikan, dalam hal ini kurikulum. Penelitian ini bertujuan untuk menguji status, segala sesuatunya dipertimbangkan, mulai dari guru, fasilitas belajar, siswa dan kemitraan sekolah yaitu komite sekolah (orang tua siswa). Di satu sisi kesiapan sebagian guru dalam penguasaan teknologi masih belum optimal sebagai tuntutan pembelajaran jarak jauh dan sekolah belum optimal dalam mensosialisasikan kurikulum pembelajaran mandiri atau pemberlakuan kurikulum di masa pandemi. Penelitian ini menggunakan teknik subyektif ilustratif yang berarti menganalisis dan kemudian menggambarkan masalah secara jelas, bersumber dari penelitian kepustakaan dengan pendekatan realisme metafisik. Untuk membantu siswa yang terkena dampak pandemi dan kemungkinan tertinggal, guru diwajibkan untuk menyelesaikan evaluasi gejala. Efek samping dari penilaian digunakan sebagai alasan untuk memilih metode pembelajaran dan memberikan solusi atau latihan tambahan kepada siswa yang hasil belajarnya belum optimal. Oleh karena itu, diperlukan pendekatan pendidikan yang humanistik. Konsep pendidikan humanistik bertujuan agar manusia memiliki kesadaran, kebebasan, dan tanggung jawab sebagai individu tetapi sebenarnya hidup dalam masyarakat.
\end{abstract}

\section{A B S T R A C T}

The curriculum is something that cannot be avoided in interacting with the educational environment. Covid-19, which has become a pandemic in more than 200 countries in the world, demands changes in various fields, including education, in this case the curriculum. This study aims to examine the status, all things considered, ranging from teachers, learning facilities, students and school partnerships, namely the school committee (parents of students). on the one hand, the readiness of some teachers in mastering technology is still not optimal as a demand for distance learning and the school is not yet optimal in disseminating the curriculum for independent learning or the enactment of the curriculum during the pandemic. This investigation utilizes an illustrative subjective technique which means analyzing and afterward describing the problem obviously, sourced from library research with metaphysical realism as the approach. To help understudies influenced by the pandemic and possibly left behind, instructors are required to complete a symptomatic evaluation. The aftereffects of the appraisal are utilized as the reason for choosing learning procedures and giving healing or extra exercises to understudies who are generally given up. Therefore, we need a humanistic educational approach. The concept of humanistic education aims to make humans have awareness, freedom, and responsibility as individuals but in fact live in society.

\section{INTRODUCTION}

The issuance of the assertion of COVID-19 as a sickness pandemic for the entire world on January 30, 2020 the World Health Organization (WHO) (Sohrabi et al., 2020) said that the episode tremendously affected a few. enormous number of individuals from different areas all throughout the planet no matter what (El-Dairi \& House, 2019; Peng et al., 2020), agribusiness (Bochtis et al., 2020; VINCENT et al., 2020), producing (Chingiz, 2020), energy (Barszcz et al., 2021) and socio-monetary constructions (Dobrea et al., 2021; Nicola et al., 2020). The instruction area is currently not, at this point insusceptible from the quick effect of the COVID-19 pandemic, as it fundamentally affects all degrees of school structures all throughout the planet from essential, optional, pre-school to college and has likewise prompted the scratch-off or deferment of scholarly gatherings. (Gilmartin et al., 2020; Panesar et al., 2020). One of the guidelines or activities being trailed by the global schooling area worldwide with an end goal to stop the spread of this illness includes the conclusion of every instructive organization (Alsafi et al., 2020; Nash \& Churchill, 2020), additionally influences in excess of 900 million understudies around the world (Longhurst et al., 2020). 
Understudies, instructors, progresses in examination, controllers, and networks impact the educational plan applied in advanced education (Jeffery et al., 2019). This impact urges advanced education establishments to change learning content, learning results, instructive methodologies, instructive conditions, evaluation strategies and learning conditions identified with the applied educational plan (Baatar et al., 2018). Adjustment of the components of this educational program can be supposed to be an arranged educational plan change (Harrison et al., 2018). The arranged educational plan change is an interaction of creating educational program that is overseen in instructing and evaluating materials, techniques and systems that are viewed as new by expected implementers (Harrison et al., 2018). Consequences of educational program changes that are effectively applied to instructors who are enabled through related staff advancement exercises, use of best practices in training, improvement of the schooling framework, and understudies who show the normal outcomes at graduation (Burke et al., 2019).

Being associated with arranged educational program changes affects the monetary parts of the school as it requires a huge interest in material asset perspectives. An illustration of such venture is for the advancement of expert schooling including arranged educational plan changes (Sadeghnezhad et al., 2020; Van Schalkwyk et al., 2020). What's more, the iterative cycle related with arranged educational program changes among partners and administrative specialists adds to the speculation of time required (Grant, 2018). The result of the arranged changes to the educational program is the execution of the educational plan as portrayed in the educational program archive (Wong et al., 2019) portray the execution of the arranged educational plan as subject to the "seeing eye", in which every teacher can utilize their perspectives in deciphering and establishing the educational program depicted. (Van Melle et al., 2019) support this view by portraying the elements of educational plan execution by including the affectability of the educational plan to different factors like teachers, understudies and the instructive climate. This affectability to job players and the instructive climate opens the educational plan to educational program deviations. (Adams et al., 2018) depict educational plan change as a hazardous cycle that outcomes in contrasts between the carried out educational program and those portrayed in the endorsed archives. On account of educational program deviations, the educational program that was implemented ultimately returned to look like its pre-imaginative progenitors. Educational program deviations are the consequence of an all-around oversaw educational plan change measure, which sabotages the assets and venture made during arranged educational program changes.

The government together with various parties related to the education sector carry out a structured continuous evaluation to obtain an acceptable academic policy and apply at various levels of education without causing problems in the future. The National Education System explains that however education was created to empower human resources with character and morals (Prakoso, MA. et al., 2020). Various policies that must cover the development of the potential of the individual itself, which in essence are the main qualities for advancing a country. Academic policy is actually one of the many ways that help the process of achieving the goals of the educational process. Increased access to education is one of the goals of implementing the planned education system (Aisyah et al., 2020). An honest education system will certainly be able to become a transmission and transformation in developing values and morals so as to give birth to awareness of behavior that is commendable and accepted by the community (Munawwaroh, 2019). In addition, the existence of a centralized education system is ready to accommodate the differences that are the advantages of each individual so that this can become an advantage. Differences are no longer a big challenge, but rather complement the existing system (Sofyan et al., 2020). Currently, the government has set a new in the field of schooling as an independent learning curriculum which is expected to become an alternative policy to solve problems in education. There are four important points that are of concern to the government in implementing this policy which includes the implementation of the national standard school exam (USBN), the implementation of the national exam (UN), the design of the learning process (RPP), and zoning regulations for the admission of new students (PPPDB) (M. Tohir, 2019). The four main principles in implementing the Merdeka Belajar curriculum are more focused on freedom and accessibility given to schools to carry out the educational process based on the resources they have and refer to educational goals and ideals (Arifin \& Muslim, 2020; Mu'amalah, 2020; Nasution, 2020).

In practice, the Independent Learning Curriculum Policy finds many obstacles. The Independent Learning Curriculum must be able to ensure that there are no differences in treatment for certain gender and also ensure accessibility for children with unique desires, even though there are still many obstacles to be faced (Asfiati \& Mahdi, 2020). The Independent Learning Curriculum must also pay attention to events that may be happening in its implementation, such as in modern outbreaks, especially the Covid-19 pandemic. The Covid-19 pandemic is indeed one of the sudden conditions in which knowledge of healing methods is limited so that this can be another effort faced with assistance using a coverage manager 
(Abidah et al., 2020). In addition, because the implementation is left to instructors at school, gaining knowledge about media, obtaining technical knowledge and weather science that is conducive and directed can be another effort for instructors to make this curriculum successful (Ramadania \& Aswadi, 2020). Although conceptually, the Merdeka Belajar curriculum has a tremendous influence on most of the achievement of learning achievement, but seeing the many obstacles faced in various areas of implementing the independent curriculum, researchers are interested in researching the Management of the Independent Learning Curriculum during the Covid 19 Pandemic.

\section{METHODS}

This investigation utilizes an enlightening subjective technique which means dissecting and afterward depicting the issue plainly, sourced from library research with metaphysical realism as the approach. The data sources of this research are secondary data, including journals, online newspapers, web and literature books related to the curriculum, both domestic and foreign sources. Qualitative data analysis consists of three activity lines that occur simultaneously, namely categorization, data reduction, data presentation, and conclusion or verification. The approach used is the education and science approach management education, including curriculum and its development. This method is applied to see and understand objects research (a person, institution, society and so on) based on facts which appears as it is (natural paradigm). The subjects of this study were teachers from schools that had implemented an emergency curriculum during the pandemic. Because this study uses a qualitative method, the data processing method is carried out by describing the data in the form of regular, sequential, logical, non-overlapping, and effective sentences so as to facilitate understanding and interpretation of the data. Among them are through the stages: data checking, classification, verification, analysis, and making conclusions. the instrument used in this research is google form.

\section{RESULT AND DISCUSSION}

\section{Result}

In accordance with the demands of the global era, now the curriculum is called a modern curriculum which is more oriented towards life skills, self-development, political development, law, economy, industry, and socio-culture to create an orderly world civilization. Global era with various problems, such as; economics, politics, law, socio-culture, all of which require a realm of practice with the requirements of information and communication technology. This form of development is related to aspects that require attention, maintenance, teaching, education and guidance in a relatively long period of time. Likewise, the development of the current curriculum. To facilitate understanding of the factors of curriculum development, it is necessary to master the curriculum foundation which includes four things. First, philosophical, which is looking for the correct educational goals in the life of a particular community. Second, psychological, which is in accordance with the psychological development of the child. Third, sociological, which is in accordance with the situation/community needs. And organizational, which is relevant to the form in which the lesson is delivered. The factors that influence curriculum development in general are the goals to be achieved through various methods, the demands of the global community, content or material that is adapted to the development of science and technology, as well as the psychological conditions of students.

The educational program in instructive units in uncommon conditions gives adaptability to schools to pick an educational plan that suits understudy adapting needs. The execution of the educational program in uncommon conditions expects to give adaptability to instructive units since, it is the training unit that comprehends and comprehends the longings of understudies and partners as clients of schooling. In the educational program, fundamental capabilities for each subject are diminished so educators and understudies can zero in on fundamental skills and essential abilities for keeping learning at the following level. The Ministry of Education and Culture additionally gives learning modules to help the taking in measure from home by including movement-based learning portrayals for educators, guardians, and understudies. Accordingly, it is trusted that understudies won't be troubled with requests to finish all educational program accomplishments for class advancement and graduation, and that the execution of the educational plan is legitimate until the finish of the school year. Up to this point, as per a top to bottom investigation of Covid-19, even in mid-2021, portions of Indonesia actually can't encounter up close and personal learning like previously. To help understudies influenced by the pandemic and possibly left behind, instructors are required to complete an indicative appraisal. The non-intellectual appraisal is pointed toward estimating the mental angles and passionate states of understudies, for 
example, the mental and social enthusiastic prosperity of understudies, the understudies 'pleasure while concentrating from home, and the state of the understudies' families. The aftereffects of the evaluation are utilized as the reason for choosing learning procedures and giving therapeutic or extra exercises to understudies who are generally given up.

\section{Discussion \\ Simplification of The Curriculum During the Covid-19 Pandemic}

Big changes occurred in the world of education during the Covid-19 pandemic. These changes are identified with systems, methods and learning processes. Education is no longer in the classroom but on computer screens and smartphone. Known as online learning, online or remote learning. Face-to-face learning has been abandoned not because it is considered closed and understood as a traditional model but initially more because it avoids the transmission of Covid-19. Online schools are a solution for continuing to carry out teaching and learning activities amid the widespread spread of the corona virus. This change, of course, begins with a curriculum change that adapts to the Covid-19 pandemic situation, which is known as the emergency curriculum Education unit level curriculum that is prepared and implemented by educational units in an emergency period with due observance of the Emergency Curriculum Guide on the applicable provisions as well as the limitations of each education unit in an emergency period. The emergency period referred to is not only during the emergency period of the Corona Virus Disease outbreak, but also applies to the emergency period due to natural disasters, riots and so on.

There are two curriculum contexts, namely students and teachers where the relationship between the curriculum and the needs of students must always occur and be active. So in the Covid-19 situation the curriculum becomes something that needs to be adjusted according to the situation. Whatever curriculum is simplified or not, an educator must always interact so that learning must be adapted to the context of the school and the student is in. Learning innovation without leaving the principle of implementing learning from home during the Covid-19 era. These principles are as follows: (1) the physical and mental safety and health of students, educators, heads of education units and all members of education units are the main considerations in implementing learning from home. (2) Home learning exercises are done to give significant learning encounters to understudies, without being troubled with requests to finish all educational program accomplishments. (3) Learning from home can zero in on fundamental abilities training, including in regards to the Covid-19 pandemic. (4) Learning materials are comprehensive as per the age and level of training, social setting, character and sort of explicitness of understudies. (5) Activities and tasks during gaining from home may fluctuate between locales, schooling units and understudies as per their individual advantages and conditions, incorporating thinking about holes in admittance to taking in offices from home. (6) The learning results of understudies while gaining from home are given subjective and helpful input from the educator without being needed to give quantitative scores. (7) Promoting positive patterns of interaction and communication between teachers and parents/guardians (Winarni \& Syahrial, 2020).

This is to ensure that the objectives of implementing Learning From Home during the Covid-19 emergency are achieved, in particular to: Ensure the satisfaction of understudies' privileges to get instructive administrations during the Covid-19 crisis; Protect training unit occupants from the unfavourable impacts of Covid-19; Prevent the spread and transmission of Covid-19 in schooling units; Ensuring the satisfaction of psychosocial support for teachers, understudies and guardians A student during the Covid-19 period should have the principle of being able to develop, be responsible for studies, learning does not need face-to-face and teacher explanations are not enough, so students must have the awareness to continue learning. Thinking of students and teachers like this will lead to independence of students in learning. The Covid-19 pandemic can also be used as a momentum for schools to carry out learning extensively online/online and across regions (which have so far been limited and increased teacher creativity in delivered learning).

\section{Curriculum Development Innovations in the Covid-19 Pandemic}

Currently, with the new era, it is possible to carry out face-to-face activities using health protocols, but if face-to-face learning is not possible, learning will automatically use online learning. Online learning is learning without face to face physically but can still face to face virtually like using video conferencing. Online learning is sometimes referred to as full online. Online learning only eliminates the face-to-face process of blended learning. What is done during online learning without eliminating the essence of 6C, which states that 21st century learning has a term known as 6C, namely: critical thinking, communication, collaboration, Citizenship, Creativity and connectivity (Andersen \& Munksby, 2018). The 
points that must be done in the learning process must be carried out in any circumstances, including in the Covid-19 era. Here are some innovations that can be done in online learning.

Using a Learning Management System (LMS) to create virtual classes. Virtual Classes are the first thing that must be done before starting online learning, virtual classes will replace physical classes in schools and colleges. In this virtual class, there are also teaching materials, reference links, assignments and so on. This virtual class can use a Learning Management System (LMS) such as Moodle, Google Classroom, Microsoft Teams, Search Results, Schoology, Edmodo and so on. Even the Ministry of Education and Culture has also provided an LMS called the Indonesian Online Learning System. Through this LMS, students can learn only using internet media. Through this LMS, teachers will also easily conduct assessments and evaluate effective learning. Video conferencing as a substitute for eye to eye learning, there are numerous applications that offer this facility. Video conferencing has features that can make presentations virtually, some video conferencing applications even provide white board features that can be written digitally for learning needs. Here are some applications that can be selected for video conferencing: Zoom, Google Meet, Cisco WebEx, Microsoft Teams and so on. Video learning is one of the innovations that can be carried out in the Covid-19 era to support the learning process. In contrast to video conferencing, in video learning teachers can make teaching videos to be given to students, this is so that students can watch the learning videos over and over again. Just like the one on Massive Open Online Courses (MOOC) (Uran, 2018),There are many applications for making teaching videos such as Filmora, KineMaster, and so on. This video can be distributed via Youtube or an LMS which is used for the teaching and learning process. Students can also learn for free with MOOCs such as udemy, coursera, and so on. Even so, the videos that have been watched by students will be able to be discussed in virtual meetings either through LMS or via video conference.

Simulation Based Learning is a substitute for practicum activities carried out in laboratories, but because of the Covid-19 era this cannot be done so that teachers can use virtual case simulations. There are lots of software for doing simulations. Gamification in learning is a game technique that is collaborated with learning. Examples of gamification include role-playing simulations, augmented reality, interactive videos, and games to answer questions individually or in groups. Some software that can be used for gamification such as kahoot, quizziz and so on. All of that, can be synchronized with the LMS used. This can encourage students to play while learning. We can judge students through speed, cohesiveness, skills in completing games. With gamification it can increase the dexterity of students. So innovation is change, in this case a change due to the Covid-19 pandemic situation. These changes occur in all sectors, especially the education sector. Students can no longer study normally going to school but study at home with the guidance of their parents. Teachers interact with students remotely using online modes (in the network) with the help of internet services.

This curriculum innovation plays a strategic role because it will come into direct contact with various parties, especially students. This curriculum innovation actually implies a series of changes made by curriculum developers to adapt to environmental developments. Thus, there will be changes in terms of objectives, content and learning materials. These three points are included in the curriculum component which is the scope of work in the field of teaching and learning activities. Although not all curriculum components are included in the curriculum definition. The curriculum component is divided into 4 parts, namely: 1) Objectives, 2) Learning materials, 3) Teaching and learning process, 4) Assessment. This opinion has been largely agreed by curriculum developers in Indonesia from the 1990s to the present decade. The curriculum components are related to one another, because every curriculum development activity is always directed at certain educational goals, for example character building, science and technology mastery or work preparation. In order to achieve this goal, content or material that is relevant to the previous goal is needed, then the material is conveyed to students with a certain time period and method. The end of the cycle is an evaluation to determine the effectiveness of the previously designed curriculum and the level of mastery of the material mastered by students.

\section{Implementation of Online Based Learning in the Middle of the Covid-19 Pandemic}

Regarding the Covid-19 pandemic period which had a significant impact on the Indonesian education sector, in Circular Number 4 of 2020 concerning the Implementation of Education in the Coronavirus Disease Emergency Period. There are 6 (six) important points contained in the circular letter in connection with the implementation of educational policies that must be addressed by school principals, teachers, students, and all school members, namely 1) Implementation of National Examinations, 2) Learning Process from Home, 3) School Examinations, 4) Graduation, 5) New Student Admissions, and 6) School Operational Assistance Funds. The government policy with the Minister of Education and Culture Circular No. 4 of 2020 provides several differences or changes in the implementation of education compared to previous years. Among them is the implementation of the 2020 
national exam (UN). UN participation is not a requirement for student graduation and is not a requirement to enter college.

Furthermore, face-to-face matters in administering school exams may not be done, except for those that have been done before the publication of this circular. School exams can be carried out in the form of a portfolio of previously obtained report cards and achievements, assignments, online tests, and/or other forms of remote assessment. Schools that have implemented school exams can use school exam scores to determine student graduation. As to from home, this is additionally another thing in the execution of educating and learning exercises for understudies and understudies. Numerous schools and grounds in Indonesia are executing distance showing learning through on the web. The Minister of Education and Culture stressed that on the web/significant distance learning is done to give significant learning encounters to understudies, without being troubled with requests to finish all educational program accomplishments for class advancement and graduation. On the web/distance learning is centered around expanding understudies' comprehension of the Covid and the Covid-19 flare-up. Proof or results of learning exercises are given subjective and helpful criticism from the educator, without being needed to give a score/esteem.

This approach gave by the public authority regarding education certainly has its own challenges for education providers and students and their families. The pros and cons of this policy are of course there, the ease and difficulty in its implementation also have the same opportunity. The advantages and disadvantages of this policy are always there. However, the most important thing is not to let the teaching and learning process and the education process stop completely. Do not be suspended animation under any circumstances. The pulse of education must always be alive; education must continue to stretch in order to achieve the national educational goals set by the government. All parties have the responsibility to ensure the continuity and process of education for all of the nation's children. Education is a shared responsibility not only of government, but also of schools (teachers), and families (parents). Finally, with the government policy regarding the execution of instruction during the Covid-19 pandemic, it created a new way of implementing teaching starting from elementary schools to universities. All elements involved in the educational process are getting used to doing the online learning process using the internet or learning online remotely.

Basically, the presence of the corona virus around the world accelerates the implementation of the Era 4.0 learning model known as online learning or the term e-learning, including in Indonesia. In this case, all levels of education ranging from elementary, secondary, upper to higher education throughout Indonesia must be closed and undergo the learning model from home only. Basically the presence of the corona virus around the world has accelerated the implementation of the Era 4.0 learning model known as online learning or the term e-learning, including in Indonesia. In this case, all levels of education ranging from elementary, secondary, upper to higher education throughout Indonesia must be closed and undergo the learning model from home only. In an effort to meet quality education, educators must create various innovations as needed in the modern era 4.0 industrial revolution. The corona virus pandemic or covid-19 requires all parties to be able to adapt to the use of communication and information technology, including educators, including teachers and lecturers. For some teachers and lecturers, teaching directly in the classroom (offline) is more comfortable and effective in transferring knowledge than online. However, it needs to be understood and realized that times have changed and the digital world offers easy access to application applications that support online learning media.

In this millennial era, online learning is an opportunity for all elements of education to develop it sustainably, as a transition momentum from conventional learning. This means that online learning does not only stop when this pandemic end, but studies and evaluations are still carried out in stages in realizing the effectiveness of learning outcomes. This online learning provides opportunities for teachers or lecturers to foster academic interaction that is not limited by time and space. This is in accordance with the program of the Minister of Education and Culture, specifically Freedom of Learning, which does not bind students to class (Al Ayubi \& Nurul Islami, 2020). Learning methods in the 4.0 era require a change in learning strategies from conventional ones to online digital learning. The current reality, not only due to the demands of the times to apply online learning, but the conditions of the corona pandemic, inevitably all education stakeholders including teachers or lecturers, students or students, parents must work together to implement online learning in order to follow government recommendations.

\section{CONCLUSION}

The curriculum is something that cannot be avoided in interacting with the educational environment. Covid-19, which has become a pandemic in more than 200 countries in the world, demands changes in various fields, including education, in this case the curriculum. Various components of the 
curriculum have undergone changes and adjustments. The simplified curriculum means that an educator must be able to adapt the material he presents to the conditions of the students. The curriculum is implemented with the principle of independent learning and student-centered, so it requires creativity and innovation to deal with these conditions. During the Covid-19 pandemic, instructors are needed to continue to be able to provide learning based on health protocols. The Ministry of Education and Culture prepared an emergency curriculum during the Covid-19 pandemic where there were simplifications regarding basic competencies and also prepared learning modules and video material so that students could learn independently, so that the teaching and learning process continued to run well, even though it was full of limitations due to the pandemic. In practice, there is no ideal learning pattern, it all depends on the conditions and situations that occur. Especially during an outbreak like now, which requires the learning process to use online media. All patterns that are applied have pros and cons, but as a wise educator one must be able to prioritize many benefits and reduce disadvantages. These patterns should refer to the objectives of national education which prioritize the emergence of a nation that is quality, civilized, independent, and competitive. Therefore, we need a humanistic educational approach. The concept of humanistic education aims to make humans have awareness, freedom, and responsibility as individuals but in fact live in society.

\section{REFERENCES}

Abidah, A., Hidaayatullaah, H. N., Simamora, R. M., Fehabutar, D., \& Mutakinati, L. (2020). The Impact of Covid-19 to Indonesian Education and Its Relation to the Philosophy of "Merdeka Belajar." Studies in Philosophy of Science and Education, 1(1), 38-49. https://doi.org/10.46627/sipose.v1i1.9.

Adams, M., Rodriguez, S., \& Zimmer, K. (2018). Studying cultural relevance in online courses: A thematic inquiry. Online Learning Journal, 22(4), 361-381. https://doi.org/10.24059/olj.v22i4.1262

Aisyah, H., Maulana, I. T., Rahmelina, L., \& ... (2020). Implementasi Teknologi Positif dalam Meningkatkan Kualitas Pendidikan. Journal of Character ..., 3(1), 86-94.

Al Ayubi, S., \& Nurul Islami, W. (2020). Aktualisasi Profil Guru Nahdlatul Ulama Inspiratif dalam Menghadapi Tantangan Revolusi Industri 4.0. Syaikhuna: Jurnal Pendidikan Dan Pranata Islam, 11(1), 48-63. https://doi.org/10.36835/syaikhuna.v11i1.3841.

Alsafi, Z., Abbas, A. R., Hassan, A., \& Ali, M. A. (2020). The coronavirus (COVID-19) pandemic: Adaptations in medical education. International Journal of Surgery, 78, 64-65. https://doi.org/10.1016/j.ijsu.2020.03.083.

Andersen, M. F., \& Munksby, N. (2018). Didactical Design Principles to Apply When Introducing Studentgenerated Digital Multimodal Representations in the Science Classroom. Designs for Learning, 10(1), 112-122. https://doi.org/10.16993/dfl.100.

Arifin, S., \& Muslim, M. (2020). Tantangan Implementasi Kebijakan"Merdeka Belajar, Kampus Merdeka" Pada Perguruan Tinggi Islam Swasta Di Indonesia. Jurnal Tawadhu, 4(1), 1-11.

Asfiati, A., \& Mahdi, N. I. (2020). Merdeka Belajar bagi Anak Kebutuhan Khusus di SLB Kumala Indah Padangsidimpuan. Kindergarten: Journal of Islamic Early Childhood Education, 3(1), 59. https://doi.org/10.24014/kjiece.v3i1.9620.

Baatar, A., Sandag, O., \& Nyamjav, S. (2018). Study of Attitudes towards Interprofessional Education, Team Works and Their Barriers-Based on Survey from Mongolian National University of Medical Sciences Faculties. Cent Asian J Med Sci, 4(3), 220-229. https://doi.org/10.24079/CAJMS.2018.09.008.

Barszcz, M., Montusiewicz, J., Nowicki, T., \& Kayumow, R. (2021). 3D Modelling Of Silk Road Artefacts As A Topic For Remote Professional Student Vocational Internships During The Covid-19 Pandemic. March, 3918-3926.

Bochtis, D., Benos, L., Lampridi, M., Marinoudi, V., Pearson, S., \& Sørensen, C. G. (2020). Agricultural workforce crisis in light of the COVID-19 pandemic. Sustainability (Switzerland), 12(19). https://doi.org/10.3390/su12198212.

Burke, M., Kearns, M., Curran, M., \& Collier, D. (2019). Inter-professional development for student nurses. International Journal of Integrated Care, 19(4), 257. https://doi.org/10.5334/ijic.s3258.

Chingiz, I. (2020). Transformation of the conditions of socio-economic development of Azerbaijan in the post-pandemic period (by September 2020). Journal of Geography, Politics and Society, 10(4), 1-7. https://doi.org/10.26881/jpgs.2020.4.01.

Dobrea, R. C., Gole, I., \& Rotaru, C. (2021). Globalization - a Cause or a Solution for Corona Economic Crisis. SHS Web of Conferences, 92, 01008. https://doi.org/10.1051/shsconf/20219201008.

El-Dairi, M., \& House, R. J. (2019). Optic nerve hypoplasia. In Handbook of Pediatric Retinal OCT and the Eye-Brain Connection (pp. 285-287). https://doi.org/10.1016/B978-0-323-60984-5.00062-7. 
Gilmartin, H. M., Connelly, B., Hebbe, A., Battaglia, C., \& Kwan, B. M. (2020). Assessing the Impact of Remote Work During COVID-19 on Clinical and Translational Scientists and Staff in Colorado. Journal of Clinical and Translational Science, 1-26. https://doi.org/10.1017/cts.2020.570.

Grant, J. (2018). Principles of curriculum design. Understanding Medical Education: Evidence, Theory, and Practice, 71-88. https://doi.org/10.1002/9781119373780.ch5.

Harrison, R. A., Harrison, A., Robinson, C., \& Rawlings, B. (2018). The experience of international postgraduate students on a distance-learning programme. Distance Education, 39(4), 480-494. https: //doi.org/10.1080/01587919.2018.1520038.

Jeffery, K. A., Pelaez, N. J., \& Anderson, T. R. (2019). Using expert data to inform the use of research methods and representations to enhance biochemistry instruction and textbook design. Biochemistry and Molecular Biology Education, 47(5), 513-531. https://doi.org/10.1002/bmb.21255.

Longhurst, G. J., Stone, D. M., Dulohery, K., Scully, D., Campbell, T., \& Smith, C. F. (2020). Strength, Weakness, Opportunity, Threat (SWOT) Analysis of the Adaptations to Anatomical Education in the United Kingdom and Republic of Ireland in Response to the Covid-19 Pandemic. Anatomical Sciences Education, 13(3), 301-311. https://doi.org/10.1002/ase.1967.

M. Tohir. (2019). Merdeka Belajar. In Kementerian Pendidikan Dan Kebudayaan.

Mu'amalah, K. (2020). Perubahan, Merdeka Belajar Sebagai Metode Pendidikan Islam dan Pokok. Jurnal Tawadhu, 4(1), 977-994.

Munawwaroh, A. (2019). Keteladanan Sebagai Metode Pendidikan Karakter. Jurnal Penelitian Pendidikan Islam, 7(2), 141. https://doi.org/10.36667/jppi.v7i2.363.

Nash, M., \& Churchill, B. (2020). Caring during COVID-19: A gendered analysis of Australian university responses to managing remote working and caring responsibilities. Gender, Work and Organization, 27(5), 833-846. https://doi.org/10.1111/gwao.12484.

Nasution, A. G. J. (2020). Diskursus Merdeka Belajar Perspektif Pendidikan Humanisme. Al-Arabiyah: Jurnal Pendidikan Bahasa Dan Sastra ..., 6(1).

Nicola, M., Alsafi, Z., Sohrabi, C., Kerwan, A., Al-Jabir, A., Iosifidis, C., Agha, M., \& Agha, R. (2020). The socioeconomic implications of the coronavirus pandemic (COVID-19): A review. In International Journal of Surgery (Vol. 78). IJS Publishing Group Ltd. https://doi.org/10.1016/j.ijsu.2020.04.018.

Panesar, K., Dodson, T., Lynch, J., Bryson-Cahn, C., Chew, L., \& Dillon, J. (2020). Evolution of COVID-19 Guidelines for University of Washington Oral and Maxillofacial Surgery Patient Care. Journal of Oral and Maxillofacial Surgery, 78(7), 1136-1146. https://doi.org/10.1016/j.joms.2020.04.034.

Peng, X., Xu, X., Li, Y., Cheng, L., Zhou, X., \& Ren, B. (2020). Transmission routes of 2019-nCoV and controls in dental practice. International Journal of Oral Science, 12(1), 1-6. https://doi.org/10.1038/s41368-020-0075-9.

Prakoso, MA., D. B. H., Ramadani, Z., \& Rahmah, B. (2020). Best Pratices of Character Education in Leading Schools in Bandung. Indonesian Journal of Educational Assesment, 3(1), 61. https://doi.org/10.26499/ijea.v3i1.61.

Ramadania, F., \& Aswadi, D. (2020). Blended Learning dalam Merdeka Belajar Teks Eksposisi. STILISTIKA: Jurnal Bahasa, Sastra, Dan Pengajarannya, 5(1), 10-21. https://doi.org/10.33654/sti.v5i1.1014.

Sadeghnezhad, M., Nabavi, F. H., Najafi, F., Kareshki, H., \& Esmaily, H. (2020). Academic-Service Partnership: Development and Psychometric Evaluation of Achieving Mutual Benefits Scale (AMBS). 1-16. https://doi.org/10.21203/rs.2.22814/v1.

Sofyan, D., Boerieswati, E., \& Asmawi, M. (2020). Ability to Teach Indonesian Language in Elementary schools: Comparative Study of Teachers who have taken Professional Education and have not Participated in Professional Teacher Education. International Journal of Multicultural and Multireligious Understanding, 6(6), 781-787. https://doi.org/10.18415/ijmmu.v6i6.1214.

Sohrabi, C., Alsafi, Z., O’Neill, N., Khan, M., Kerwan, A., Al-Jabir, A., Iosifidis, C., \& Agha, R. (2020). World Health Organization declares global emergency: A review of the 2019 novel coronavirus (COVID19). International Journal of Surgery, 76, 71-76. https://doi.org/10.1016/j.ijsu.2020.02.034.

Uran, L. L. (2018). Evaluasi implementasi KTSP dan Kurikulum 2013 pada SMK se-Kabupaten Belu, Nusa Tenggara Timur. Jurnal Penelitian Dan Evaluasi Pendidikan, 22(1), 1-11. https://doi.org/10.21831/pep.v22i1.13309.

Van Melle, E., Frank, J. R., Holmboe, E. S., Dagnone, D., Stockley, D., \& Sherbino, J. (2019). A Core Components Framework for Evaluating Implementation of Competency-Based Medical Education

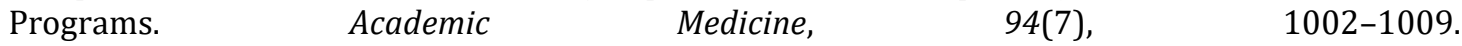
https://doi.org/10.1097/ACM.0000000000002743.

Van Schalkwyk, S. C., Kiguli-Malwadde, E., Budak, J. Z., Reid, M. J. A., \& de Villiers, M. R. (2020). Identifying research priorities for health professions education research in sub-Saharan Africa using a 
modified Delphi method. BMC Medical Education, 20(1), 1-19. https://doi.org/10.1186/s12909020-02367-z.

Vincent, A., Mamzer, H., Ng, Z., \& Farkas, K. J. (2020). People and Their Pets in the Times of the Covid-19 Pandemic. Society Register, 4(3), 111-128. https://doi.org/10.14746/sr.2020.4.3.06.

Winarni, S., \& Syahrial. (2020). Inovasi Kurikulum dan Pembelajaran Pada Masa Pandemi Civid-19. Jurnal Ilmiah Wahana Pendidikan Https://Jurnal.Unibrah.Ac.Id/Index.Php/JIWP, 6(3), 317-322. https://doi.org/10.5281/zenodo.3960178.

Wong, S. Y., Liang, J. C., \& Tsai, C. C. (2019). Uncovering Malaysian Secondary School Students' Academic Hardiness in Science, Conceptions of Learning Science, and Science Learning Self-Efficacy: a Structural Equation Modelling Analysis. Research in Science Education. https://doi.org/10.1007/s11165-019-09908-7. 